\title{
MARTIN KRAKOWSKI
}

\section{Brèves communications : "Random file"}

Revue française d'automatique, d'informatique et de recherche opérationnelle. Recherche opérationnelle, tome 5, $\mathrm{n}^{\circ} \mathrm{V} 2$ (1971), p. 111-112.

$<$ http://www.numdam.org/item?id=RO_1971_5_2_111_0>

(C) AFCET, 1971, tous droits réservés.

L'accès aux archives de la revue « Revue française d'automatique, d'informatique et de recherche opérationnelle. Recherche opérationnelle » implique l'accord avec les conditions générales d'utilisation (http://www.numdam.org/ legal.php). Toute utilisation commerciale ou impression systématique est constitutive d'une infraction pénale. Toute copie ou impression de ce fichier doit contenir la présente mention de copyright.

\section{Numdam}

Article numérisé dans le cadre du programme

Numérisation de documents anciens mathématiques

http://www.numdam.org/ 
R.I.R.O.

(5e année, V-2, 1971, p. 111-112)

\section{Brèves communications}

\section{RANDOM FILE}

par Martin KRAKowsKI

A file contains $N$ entries which are being requested with known relative frequencies $Q_{i}$, so that

$$
\sum_{1}^{N} Q_{i}=1 .
$$

The file is random in the following sense. If the Smith record is the one requested we keep on drawing folders until we succeed in retrieving the Smith entry. However, each time we draw a "non-Smith " record we replace it, shake up the file (in order to erase any memory of ordering resulting from the search) and continue the drawing process until the entry "Smith" is found.

Suppose now that the probabilities $\boldsymbol{P}_{\boldsymbol{i}}$ of drawing the entries $i$ are under our control. One thinkable arrangement is a roulette wheel where, for instance, $P_{2}=2 P_{1}$ implies that entry $\# 2$ subtends an angle twice that of entry \#1; each record is located in the corresponding angular sector. The roulette wheel is spun until the requested entry shows up.

Another arrangement involves multiple copies of some or of all entries so that, e.g. $P_{2}=2 P_{1}$ means that entry $\# 2$ has twice as many copies as has entry \# 1 . This method is limited to rational approximations of the $P_{i}$ and good approximations may require huge files.

The problem is : Given the known relative demand frequencies $Q_{i}$, select the discretionary drawing probabilities $P_{i}$ so as to minimize the expected number of draws (tries) per search of an entry.

Let

(2) $\quad D_{i}=1 / P_{i}=$ expected \# of tries to retrieve entry $i$;

$$
\begin{aligned}
& D=\sum_{1}^{N} Q_{i} / P_{i}=\text { expected \# of tries per search; } \\
& \sum_{1}^{N} P_{i}-1=0 .
\end{aligned}
$$

Revue Française d'Informatique et de Recherche opérationnelle $\mathrm{n}^{\circ} \mathrm{V}-2,1971$. 
In order to minimize $D$ we use the method of Lagrangian multipliers and we obtain (neglecting momentarily the requirement $P_{i} \geqslant 0$ ), $\propto$ being the multiplier,

$$
\frac{\partial D}{\partial P_{i}}=-Q_{i} / P_{i}^{2}=-\propto, \quad \text { for each } i .
$$

It follows that

$$
P_{i}^{2}=Q_{i} / \propto \quad \text { and } \quad P_{i} \sim \sqrt{Q_{i}},
$$

so that the optimal $P_{i}$ is proportional to the square root of $Q_{i}$.

Therefore,

$$
P_{i}=\sqrt{Q_{i}} / \sum_{1}^{N} \sqrt{Q_{j}}
$$

Thus the requirements $P_{i} \geqslant 0$ for each $i$ are satisfied; since $\frac{\partial^{2} D}{\partial P_{i}^{2}}>0$ when (6) holds, the minimum value of (3) is

$$
D^{*}=\sum_{1}^{N} Q_{i} / P_{i}=\left[\sum_{1}^{N} \sqrt{Q_{i}}\right]^{2} \text {. }
$$

When $Q_{i}=1 / N$ for each $i$ then $P_{i}=Q_{i}$ and $D^{*}=N$.

When $Q_{1}=1$ and $Q_{i}=0$ for $i>1$ then $P_{i}=1$ and $P_{i}=0$ for $i>1$, and $D^{*}=1$, as expected.

NoTE : The result that the optimal $P_{i} \sim \sqrt{Q_{i}}$ is counter-intuitive.

Most people venture the guess $P_{i}=Q_{i}$ for the optimal probabilities. The corresponding expected number of tries per search would be $D=N$, the number of file entries, irrespective of the assumed frequencies $Q_{i}$. This guess can be very bad. If $Q_{1} \rightarrow 1$ and $Q_{k} \rightarrow 0$ for $k>1$, then the optimal $D^{*} \rightarrow 1$, while the intuitive expectation is $D=N$. 